\title{
INNOVATION AND TECHNOLOGY TRANSFER BARRIERS IN SLOVAKIA AND OTHER NEW EU MEMBER STATES
}

\author{
Štefan Luby, Ivan Chodák, Martina Lubyová \\ Institute for Forecasting, Slovak Academy of Sciences, \\ Centre of Excellence CESTA (Centre for Strategic Analysis), Bratislava, Slovak Republic
}

\begin{abstract}
The performance of European Union in terms of R\&D investment, innovations, and educational attainments generally lags behind that of its main competitors - the United States and Japan. Within the EU, the new member states from Central and Eastern Europe belong to the group of moderate innovators. As technology is the key component of the innovation system of the $2^{\text {nd }}$ generation, this paper is dedicated to discussing the methods of technology transfer applied by innovation leaders in the EU (e.g. Germany or Finland) and to identifying the factors that may represent the main stumbling blocks in the way of more effective innovation procedures in the new member states (e.g. Governments' preferences for FDI that is attracted by the relatively cheap and skilled labour force; investors' preferences for using know-how developed in their home countries; the absence of venture capital available for R\&D and technology transfers, etc.). As the situation in the new member states begins to change - wages are growing and the countries are building new research infrastructure with the help of the EU funds - a new innovation and TT paradigm enters the stage. We discuss the ways of coping with these new challenges - such as better governance in the field of patents, extended education of students in the field of innovative competences and entrepreneurial skills, deeper understanding of the operations of industry technology transfer organizations and improved access to venture capital.
\end{abstract}

Key words

EU, research and development, technology

\section{Introduction}

Innovative processes are among the key factors that facilitate the progress of contemporary societies. The definition and understanding of innovations has undergone a significant change over the past decades. The theory of innovation was found in 1911 by J. Schumpeter who specified five criteria of innovation: new

technology, new product, application of new materials, improvement of the organization of the work, and opening of new markets /1/. From methodological

point of view, innovative approach does not necessarily imply a completely new approach, but can be based on incremental improvements /2/. From the point of view of topical coverage the registry of innovations has expanded to include a broad range of issues, such as, for example, new control methods and tests, safety at work, environmental protection, more efficient use of ener- 
gy, etc. Nowadays only a small share of innovations is born in the field of research and development (R\&D).

In this paper we show that despite the innovationcenteredness of the current EU development strategies, its innovation performance is not up to the world standards. We explore the reasons for this lagging behind with a special focus on the new EU member states and other countries of the Central and Eastern Europe. We use the example of the Slovak Republic to illustrate the structural and institutional problems that hamper the innovation performance of these countries. We also point to the best practices applied by the innovation leaders that need to be adopted by the new member states in order to improve their innovation performance. We denote the new EU member states from Central and Eastern Europe as the EU 7 (the Visegrad 4 and the Baltic 3) or EU 9 (EU 7 plus Bulgaria and Romania).

1. Lagging innovation performance in Europe: European innovation leaders and followers

On a world-wide scale, Europe performs relatively weakly in terms of support to $R \& D$, application of information and communication technologies (ICT), and in particular in terms of the frequency of innovations. The European competitive gap can widen even further as the new global competitors, such as China and India, invest into $R \& D$ increasingly more resources. The European Union is lagging behind the world leaders also in the field of educational achievements. In the EU member states less than one third of population aged $25-34$ years completed tertiary education (university degree), while in the United States and Japan the shares are $40 \%$ and $50 \%$, respectively. Only two European universities rank amongst the top 20 in the Shanghai ranking. In 2013 the last edition of the evaluation protocol of implementation of Europe 2020 was published $/ 3 /$. The document provides the results for EU 27 MS, and also for Croatia, Serbia, Macedonia and world innovation leaders, like Switzerland, USA, Japan. Countries are evaluated according to 25 indicators divided into 8 groups - people, excellent research, finances, industry investments, entrepreneurial environment, intellectual property, economic effects, professionalism of innovators. Each indicator was classified between 0 and
1. The results for EU 27 in descending order are as follows (Table 1):

a) Innovation leaders - performing well above the EU average: Sweden, Germany, Denmark and Finland;

b) Innovation followers - showing performance close to that of the EU average: Netherlands, Luxembourg, Belgium, UK, Austria, Ireland, France, Slovenia, Cyprus and Estonia;

c) Moderate innovators - performance is below that of the EU average: Italy, Spain, Portugal, Czech Republic, Greece, Slovakia, Hungary, Malta and Lithuania;

d) Modest innovators - performance is well below that of the EU average: Poland, Latvia, Romania and Bulgaria.

Among the non-EU countries, Croatia and Serbia belong to moderate innovators and Macedonia to the modest innovators group, all with performance below the averages of their respective group.

\begin{tabular}{|l|c|c|}
\hline \multicolumn{1}{|c|}{ Group } & $\begin{array}{c}\text { Average perfor- } \\
\text { mance }\end{array}$ & $\begin{array}{c}\text { Growth } \\
{[\%]}\end{array}$ \\
\hline Innovation leaders & $0.75-0.65$ & 1.8 \\
\hline $\begin{array}{l}\text { Innovation follow- } \\
\text { ers }\end{array}$ & $0.65-0.48$ & 1.9 \\
\hline $\begin{array}{l}\text { Moderate innova- } \\
\text { tors }\end{array}$ & $0.48-0.27$ & 2.1 \\
\hline Modest innovators & $0.27-0.2$ & 1.7 \\
\hline
\end{tabular}

Table 1 Average performance of European innovators in 2013 and its growth during the period $2008-2012$

Source: Porras (2013)

Overall, the EU attaches top importance to the innovation policies and regulatory frameworks. Two key documents related to the filed of innovations in the European Union are the Strategy Europe 2020 and a flagship initiative Innovative Europe (of October 2010). The Europe 2020 Strategy formulates three priorities: a) growth based on knowledge and innovations, b) sustainability, c) inclusive growth - high employment and social cohesion. In 2020 investments into R\&D should reach $3 \%$ of gross domestic product in all 27 countries of EU. ${ }^{1}$ Furthermore, during the period

\footnotetext{
${ }^{1}$ Soon after publishing Europe 2020 document, the Ministers of Finance of the EU member states declared their discontent
} 
of 2014-20 a new European research program Horizon 2020 will become a decisive instrument moving Europe towards its strategic aims. The Horizon will embrace the $8^{\text {th }}$ Framework Program fused with innovations-accelerating funds. The main components of the program are represented by Excellent Science ( 24 billion $€$ ), Societal Challenges (32 billion $€$ ) and Industrial Leadership (18 billion $€$ ). The components include the following fields: enabling and industrial technologies, ICT, nano- and biotechnologies, and access to risk finance and innovation in SMEs. The total budget of Horizon 2020 approaches 80 billion $€$. Even if it is partially reduced, the programme is of paramount importance for Central and Eastern Europe countries coping with modernisation of their research and innovation infrastructure.

\section{Reasons for the lagging innovation per- formance of the new EU member states}

In the period between 2007 and 2013 the new member states received sizeable amounts from the EU structural funds. Part of them is directed to national operational programs of research, development and innovation. The amounts of these subsidies are very high in the context of domestic support of the building of new research infrastructure. For example, in Slovakia the allocation reached almost 1.2 billion $€$, in the Czech Republic 2.1 billion $€$, etc. The inflow of funds poses a high responsibility on the academic communities in terms of its efficient use for the acceleration of R\&D and innovations. At the same time, the national governments are under pressure to provide matching funds for intensive exploitation of these new facilities - a task that is not realized by many.

Lack of patenting in the $E U$ and in particular in the new member states

The situation in R\&D investments and patenting policies in world are analysed by J. Straus $/ 4 /$. Some basic conclusions are as follows: largest economies in Asia currently spend approximately 400 billion USD annually on R\&D, USA spends the same amount, while Europe spends about 300 billion USD. The consequences are already visible. In 1985 the top 5 exporters of high-tech goods in descending order were: USA, Japan, Germany,

with the $3 \%$ target and demanded introduction of outputoriented criteria of R\&D efficiency.

ISSN 1333-6371
UK, France. By 2005 the ranking has changed as follows: China, USA, Germany, Japan, Hong Kong. Chinese researchers filed 391 thousand patent applications only in 2010 while other developing countries trail behind. However, in the new EU member states from CEE the situation is alarming: its population of roughly 90 million filed less then half the number of patent applications by Austria.

\section{Labour cost trigger relocation of production ra- ther than RED}

In 2005, i.e. before the crisis, the average GDP growth rate of the seven new EU member states from Central and Eastern Europe was $5.4 \%$. By 2011 it was down to $1.8 \%$, being equal to the average growth of the EU 15 in 2005. But this GDP growth in the new member states is linked to the integration with EU market and a shift of some production from the old member states to new ones that provide cheaper labour force and other favourable conditions. A stark example of this process is Slovakia that has export/oriented processing economy with low commercialization of its own R\&D. In next $5-10$ years only a slow growth of wages is expected, therefore enterprises including SMEs will further benefit from the cheap labour force (see Table 2 for comparison). However, the rising production costs in the EU have already resulted in a gradual shift of production towards Asia, implying that sustainable growth and sound economic development require strategic approach fostering innovations and growth of competitiveness in Europe.

Table 2 Cost of labour in selected countries related to the average of OECD (100)

\begin{tabular}{|l|c|l|l|}
\hline Country & $\begin{array}{c}\text { CL } \\
\text { ratio }\end{array}$ & Country & $\begin{array}{c}\text { CL } \\
\text { ratio }\end{array}$ \\
\hline Germany & 148 & Portugal & 74 \\
\hline Netherlands & 134 & $\begin{array}{l}\text { Czech } \\
\text { Rep. }\end{array}$ & 62 \\
\hline France & 123 & Hungary & 54 \\
\hline Japan & 117 & Poland & 52 \\
\hline USA & 106 & Slovakia & 46 \\
\hline $\begin{array}{l}\text { OECD aver- } \\
\text { age }\end{array}$ & $\mathbf{1 0 0}$ & Mexico & 27 \\
\hline Canada & 94 & & \\
\hline
\end{tabular}

Source: Focus Agency, Slovakia, April 2010 
In this section we dwell briefly on the case of the Slovak Republic, which provides insights into the typical situation of a new EU member state from the CEE. In terms of the above-mentioned innovative performance $/ 5 /$, Slovakia's score is 0.33 . This ranks the country at the $20^{\text {th }}$ position, in the middle of the field of moderate innovators (above Malta and Hungary and below Greece and the Czech Republic). The score is relatively low in comparison to the EU 27 average of 0.54 and to the performance of the top innovation leader Switzerland 0.85. In order to explain the laggard position, one has to look into the structural and institutional issues. In this section we would like to expose the problems that in our view represent serious obstacles to improving the innovation performance.

In the EU 15 the $2^{\text {nd }}$ generation innovation policy tools are applied, in Slovakia $1^{\text {st }}$ generation policy still survives.

A round table discussion of the representatives of industry, academia and bank sector in 2011 on the low innovation performance of Slovakia provided the following explanations:

a) Foreign direct investment flows only into production, not into R\&D;

b) Slovak SMEs do not invest into RED and they innovate only with the state subsidies;

c) Market for venture capital is not developed yet, capital is accepted only in the form of loans, new owners are not admitted into the companies;

d) Companies in incubators are not active innovators, they benefit mostly from the low rent of premises.

As everywhere, lack of transparency in business, corruption and terrorism are considered as obstacles for innovation progress (at least the last factor is absent in Slovakia so far).

The role and importance of education system in boosting the innovative performance cannot be understated. In this regard, the Slovak government formulated the following recommendations to the tertiary education institutions in 2010: providing less specialized education, teaching more general knowledge, educating towards critical thinking and ability to gain information. Higher importance should be given to domestic and international patents. Shorter curricula for fast transfer into practice are to be developed. In terms of legislative framework, Slovakia has the basic acts on the support of science (Act 172/2005), on the state assistance (Act 231/1999), and on the stimuli for R\&D2 (Act 185/2009). In the field of intellectual property protection, Slovakia has a complete set of acts on the intellectual property rights (90/1993), patenting act (435/2001) and copyright act (618/2003). According to the Slovak legislation, employee must inform his employer about invention leading to patent. If employer does not claim his rights within 3 months, patent belongs to the author/creator. In general, there are no demands for changes of the existing legislation, although some fine-tuning of the current institutions would be of help (for example, into the patent act a grace period applied in USA should be implemented as a reasonable compromise between publishing and patenting). A dedicated innovation act is needed in order to stimulate further development in the field. Unfortunately, legislation per se is not a considerable driving force for innovations.

\section{Examples of best practices in technology transfers by innovation leaders}

This section builds mainly on our study of best practices in technology transfer (TT) in Germany during the period 2009 - 2010, the CERIM project ${ }^{3}$, and two studies carried out by the Academy of Sciences of Czach Republic /6/. We pay special attention to the institutional embeddedness of TT processes, as well as to the role of TT agencies and the availability of venture capital. The first and foremost observation relevant for the new EU member states is the large role of subsidies in the TT process: even in the innovation leading countries, $50 \%$ of income of technology transfer offices (TTO's) comes from governmental subsidies, $25 \%$ from R\&D projects and only one quarter from the real technology transfer. The Governments should understand that providing the support for innovation process is their high responsibility. Despite all the challenges of pioneering the TTOs, our experience shows that well-functioning offices are inevitable to move the innovation engine ahead.

\footnotetext{
2 Effectiveness of tax incentives is problematic at the generally low tax level of $19 \%$.

${ }^{3}$ The cooperation with technology transfer offices (TTO) like inno AG Karlsruhe or Eurogroup Consulting Milano within project CERIM was inspiring.
} 


Box 1 TTO's assessment strategies
Our empirical work showed that various
TTO's use quite similar set of criteria to
decide whether research results have a
potential for commercialization. The
main questions posed in the evaluation
of results are as follows:
a) Is the product is patented? If not, was
it published and to which extent?
b) Do you have a prototype?
c) What is the situation at the market? Is
the market of a small, medium or large
size?
d) What will be the price of materials,
ICT, equipments?
e) Are there some alternative approach-
es? Etc.
Needless to say, the Slovak owners of
tested products were not able to answer
these questions thoroughly.
Source: CERIM project (Central Europe Re-
search to Innovation Models) funded by the
European Regional Development Fund

Secondly, the TT activities and institutions in innovation leaders represent genuine $2^{\text {nd }}$ generation of TT systems that are characterized by a densely populated interface between the research and industry to overlap the "mentality"gap between these two. The $1^{\text {st }}$ generation models based on a "down hill flow" of inventions from researchers to applicators have been recognized as non-functional and have been largely abandoned by the innovation leading countries.

Thirdly, the institutional embeddedness of the TT activities in innovation leading countries is very strong. Innovations and commerce are accented as the $3^{\text {rd }}$ role of universities (along education and research) and the $2^{\text {nd }}$ role of research institutions. For example, in Germany, the institutional embeddedness of TT (Wissenstransfer or Innovationstransfer) is high including among the educational institutions. TT activities are displayed at the web pages of all universities and research institutes, including new federal states. The TT is organized via an own university office or via external company. The broad field of TT activities covers consultations, TT contracts, patents, marketing, foundation of spin-off and startup companies, exchange of knowledge, transferportals, networking, measurements, audits and ISSN 1333-6371 analyses with the own laboratory equipment. New spin-off and start-up companies are most frequent in the fields of biotechnology and health. TT activities are common in both technical and natural-science institutions; nevertheless, universities in the field of social sciences and humanities are also involved, in particular through education and consultation activities especially in the field of economics (e.g. University of Augsburg). Best examples from other countries include the agency VINNOVA in Sweden and the agency TEKES in Finland. The latter agency that was funded in 1983 distributes approximately 500 million $€$ per year for projects, especially risk projects and foresight studies. In 2007 its output represented 690 filled patents, 500 new products, 400 improved processes.

Fourthly, the availability of venture capital seems to be a sine qua non condition for achieving the innovation leading status. As an example, we name the venture capital operating institutions in Germany - Betailigungsprogram, in Finland - the agency SITRA and in Ireland - the Seed and Venture Capital System.

\section{Conclusions}

It is obvious that several current factors, such as the economic crisis, ambitions to integrate into the ERA, and building of new research infrastructure from EU structural funds will accelerate the transition of the new EU member states towards the $2^{\text {nd }}$ generation TT policy, and put pressure on increasing the pace of innovations in the region. In principle, the new EU member states face three scenarios of future development in terms of innovative performance: a) fast convergence with innovation leaders - conditioned by innovation policy with powerful interventions of government, b) slow convergence with innovation leaders, and c) a lost decade, where the innovations will eventually grow after the comparative advantage based on low labour cost and preferential treatment by the national governments will move towards other regions. To this end, the effective instruments to be applied by the new MS include the support of TT policy, more investments into R\&D, improved tax policy and state assistance, availability of venture capital, transparent tenders and procurement, good political climate, education in spirit of entrepreneurship 
and business skills. The lessons learned from examining the best practices in technology transfer in the innovation leading countries show that sine qua non conditions for achieving the innovation leading status include the large role of subsidies in the TT process, the large degree of institutional embeddedness of TT activities and institutions, the move toward genuine $2^{\text {nd }}$ generation of TT systems that are characterized by a densely populated interface between the research and industry.

\section{Acknowledgement}

This work was supported by the Centre of Excellence of the Slovak Academy of Sciences CESTA (Centre for Strategic Analysis).
Notes

/1/ Keklik, M. (2003). Schumpeter, Innovation and Growth, Ashgate Publishing Company

/2/ Baumol, W. J. (2002). The Free-Market Innovation Machine, Princeton Univ. Press

/3/ Porras, B. G., Jerzyniak, T., (coordinators), (2013). Innovation Union Scoreboard, European Commission, Brussels

/4/ Straus, J. (2012). A marriage of convenience: world economy and intellectual property from 1990 to 2012, American Intellectual Property Law Association Vo. 40, 2012, No. 4, p.633.

/5/ Porras, B. G., Jerzyniak, T., (coordinators), (2013). Innovation Union Scoreboard, European Commission, Brussels

16/ Klusáček, K., Kučera, Y., Pazour, M. (2008). White book of research and innovations in Czech Republic, Technology Center of Academy of Sciences, Czech Rep., Prague 2008, ISBN 978-80-86429-99-1 (in Czech language) 


\title{
INOVACIJE I PREPREKE U TRANSFERU TEHNOLOGIJE U NOVIM ČLA- NICAMA EU, POSEBNO U SLOVAČKOJ
}

\author{
Štefan Luby, Ivan Chodák, Martina Lubyová \\ Institute for Forecasting, Slovak Academy of Sciences, \\ Centre of Excellence CESTA (Centre for Strategic Analysis), Bratislava, Slovak Republic
}

\section{Sažetak}

Učinkovitost Europske unije u smislu istraživanja i razvoja, inovacija i pohađanja obrazovnih institucija uglavnom zaostaje za glavnim konkurentima Sjedinjenim Američkim Državama i Japanom. Unutar EU-a, nove države članice iz srednje i istočne Europe pripadaju u skupinu umjerenih inovatora. Kako je tehnologija ključna komponenta $u$ inovacijskom sustavu 2. generacije, ovaj članak je posvećen raspravi o metodama transfera tehnologije koje primjenjuju inovacijski lideri u EU (npr. Njemačka i Finska) i identificiranje čimbenika koji mogu predstavljati glavni kamen spoticanja u načinu učinkovitijih inovacijskih postupaka u novim članicama EU (npr. sklonosti vlada za izravnim stranim ulaganjima koja privlači relativno jeftinu i kvalificiranu radnu snagu; sklonosti investitora za korištenjem know-how razvijen u svojim matičnim zemljama, izostanak rizičnog kapitala na raspolaganju za istraživanje i razvoj i transfer tehnologija, itd.). Kao što se situacija u novim državama članicama počinje mijenjati - plaće rastu i zemalje grade novu istraživačku infrastrukturu uz pomoć EU fondova - nove inovacije i TT paradigme ulaze na pozornicu. Raspravlja se o načinima suočavanja $s$ novim izazovima - kao što su bolje upravljanje $u$ području patenata, prošireno obrazovanje učenika u području inovativnih kompetencija i poduzetničkih vještina, dublje razumijevanje o poslovanju industrije za transfer tehnologije i poboljšanje pristupa kapitalu.

\section{Ključne riječi}

EU, istraživanje i razvoj, tehnologija 